Vol. 2, No. 1, pp. 1-5, 2021

\title{
Identification of Various Fishing Activities and the Outpouring of Time of Women Fishermen in Cilacap Regency, Indonesia
}

\author{
Agnes Puspitasari Sudarmo ${ }^{1 *}$, Yogi Putranto ${ }^{2}$ \\ ${ }^{1}$ Department of Fishery Management Graduate Program, Faculty of Science and Technology, \\ Universitas Terbuka, Tangerang Selatan, Banten 15418, Indonesia \\ ${ }^{2}$ Student of Department of Fishery Management Graduate Program, Faculty of Science and Technology, \\ Universitas Terbuka, Tangerang Selatan, Banten 15418, Indonesia \\ *Corresponding authore-mail address: agnes@ecampus.ut.ac.id; yogiputranto30@gmail.com
}

\begin{abstract}
Fishing women have unique roles and dual roles not only as housewives but also as economic backbones. Women fishermen help their husbands work to be able to meet the needs of the family. The purpose of this research is to identify the variety of fishing activities and the outpouring of time of women fishermen in Cilacap Regency. The location of this research is at the Fish Auction Place (TPI) TPI Tegal Katilayu, TPI Menganti Kisik, and TPI Lengkong. Descriptive methods based on case studies were used in this study. The sampling method used was purposive sampling, and the number of samples taken by 55 women fishermen. The results showed that the variety of activities carried out by women fishermen were also dominated by economic activities in addition to their roles as a housewife.
\end{abstract}

Keywords: Women fishermen; outpouring time; Fish Auction Place (TPI); Cilacap

\section{Introduction}

The potential of fisheries in Cilacap regency is very abundant, where the utilization of marine potential has not been developed optimally, especially in the fishery sector, due to inadequate human resources and limited fishing facilities. One of them is the potential catch of 72,000 tons of fish, however, the utilization of capture fisheries in Cilacap regency only reaches about $21 \%$ (Pancawati, 2015). This condition is coupled with the geographical state of nature on the south coast of Cilacap where the sea waves are quite high because it is directly adjacent to the Indonesian Ocean. Working as a fisherman has high risk factors in terms of safety and uncertain income factors. Uncertain fish catches coupled with poor climatic conditions cause fishermen to sometimes not carry catches. During times of shortage, basic daily family needs such as food, clothing, boards need to be met, so the role of women fishermen at this time is very important. Fishing woman is a term for women who live in a fishing family environment as wives.

Women fishermen position in the family is as the wife of the fisherman, in addition it also has dual roles as the backbone of the family that is making a living, especially when the conditions in the sea are erratic. Women in fishing families are generally involved in making a living for their families. This showed that fishing women not only act as housewives, but also do productive activities to increase income for family (Anna, 2014; Hutapea et al., 2012). Akpaniteaku et al. (2005) stated that one of the most important commodities handled by women fishermen is fish. The role of women fishermen among others is in the activities of handling and making a variety of processed fish products. The existence of such women fishermen roles is often not seen as important by policy makers Various activities of women fishermen including ranging from the pre-production process to the post-production process that is in dismantling and handling fish ranging from landing, marketing, to fish processing. Even with the increasing recognition that women engage in fish-related activities, will give a better understanding by using socio-ecological approaches to fisheries research and management (Kleiber et al., 2015). The purpose of writing this article is to identify various fishing activities and time outpourings related to the activities of women fishermen in Cilacap Regency. 


\section{Materials and Methods}

\subsection{Time and Location of Research}

The method used in this study is descriptive case studies. Descriptive method aims to describe the symptoms or social phenomena that are happening in society, in which there are efforts to describe, record, analyze and interpret the current condition. Details of descriptive findings in the field related to fishing practices provide crucial information about the role of female fishermen. This will provide important socio-ecological information that implies understanding their roles in marine ecosystems (Kleiber et al., 2015).

\subsection{Methods}

The sampling method used is purposive sampling. Respondents in this study were women fishermen who worked at fish auctions namely TPI Tegal Katilayu, TPI Menganti Kisik, and TPI Lengkong. The number of respondents to the study was 55 women fishermen who worked at the auction site. There are 2 types of data collected in this study, namely primary data and secondary data. The primary data collected is the data of women fishermen who work in TPI. Secondary data comes from the Cilacap Regency Fishery Office, local TPI, Central Bureau of Statistics Cilacap or publication journal articles related to women fishermen and the productive outpouring of time activities carried out by women fishermen. This research data was analyzed using descriptive statistics. The data was analyzed descriptive analysis.

\section{Results and Discussion}

The research locations were conducted in three locations of Fish Auction Place (TPI) namely Tegal Katilayu TPI, TPI Menganti Kisik, and TPI Lengkong in Cilacap Regency. The location of TPI Tegal Katilayu is in the district of South Cilacap, TPI Menganti Kisik is in the district Kesugihan, and TPI Lengkong is in the District of North Cilacap. The boundaries of Cilacap Regency (Badan Pusat Statistik Kabupaten Cilacap, 2019) are as follows:

- North: Brebes and Banyumas

- East: Kebumen Regency

- South: Indonesian Ocean.

- West Side: Ciamis Regency, Banjar City and Kuningan Regency (West Java Province)

The population in Cilacap Regency in 2019 was 1.906 .849 people, the majority of them are indigenous Javanese. The population of Cilacap Regency by gender can be seen in Table 1.

Table 1. Population of Cilacap Regency by Gender

\begin{tabular}{lccc}
\hline No & Indicators & Numbers & $\%$ \\
\hline 1 & Number of & $1,906,849$ & 100 \\
& populations & & \\
2 & Male & 964,101 & 50.60 \\
3 & Female & 942,748 & 49.44 \\
\hline
\end{tabular}

Source: (Badan Pusat Statistik Kabupaten Cilacap, 2019)

\subsection{Characteristics of Respondents}

The age distribution of respondents can be seen in Table 2. The results of interviews with fishermen women were obtained that by $27.27 \%$ or as many as 15 women fishermen aged $53-58$ years, by $18.18 \%$ or as many as 10 women fishermen aged $48-52$ years. Women fishermen aged $28-32$ years only 2 respondents, aged $38-42$ years or $12.73 \%$ as many as 9 respondents, and women fishermen aged over 58 years as many as 6 respondents. It can be inferred that women fishermen over the age of 58 are still working to support their families and to help economic family sustain. 
Table 2. Distribution Ages of Women Fishers in Cilacap Regency

\begin{tabular}{|c|c|c|c|}
\hline No & $\begin{array}{c}\text { Age Range } \\
\text { (years) }\end{array}$ & $\begin{array}{c}\text { Number of } \\
\text { respondents }\end{array}$ & $\begin{array}{c}\text { Percentages } \\
(\%)\end{array}$ \\
\hline 1 & $28-32$ & 2 & 3.64 \\
\hline 2 & $33-37$ & 6 & 10.91 \\
\hline 3 & $38-42$ & 9 & 16.36 \\
\hline 4 & $43-47$ & 7 & 12.73 \\
\hline 5 & $48-52$ & 10 & 18.18 \\
\hline 6 & $53-57$ & 15 & 27.27 \\
\hline 7 & $58-63$ & 6 & 10.91 \\
\hline & & 55 & 100.00 \\
\hline
\end{tabular}

\subsection{Variety of Daily Activities Conducted by Respondents}

Women fishermen dedicated their time in one full day 24 hours every day of their lives. The daily ritual activities started from sholat (morning prayer) at around 04.00 until the evening. From Figure 2, there were various daily activities carried out by women fishermen from morning, day, and until night. Various activities in the morning such as morning prayers, cooking for families, shopping for daily necessities to the market, preparing the needs of children and husbands, cleaning the house, washing clothes, and bathing. After completing the activities carried out in the morning at home, the women continued the activities at the fish auction site. Variety of day time activities such as selling a variety of fish landed by fishermen in TPI, drying fish, cleaned fish catches, checking the processed fish products of small traders. After the women fishermen completed their respective activities in fish auction, they will soon return home. Various of night activities can be viewed such as cooking, distribution of processed products, family gatherings and night rest/sleeping. All these daily activities run the same every day, all year round, as long as they live as fishing women.

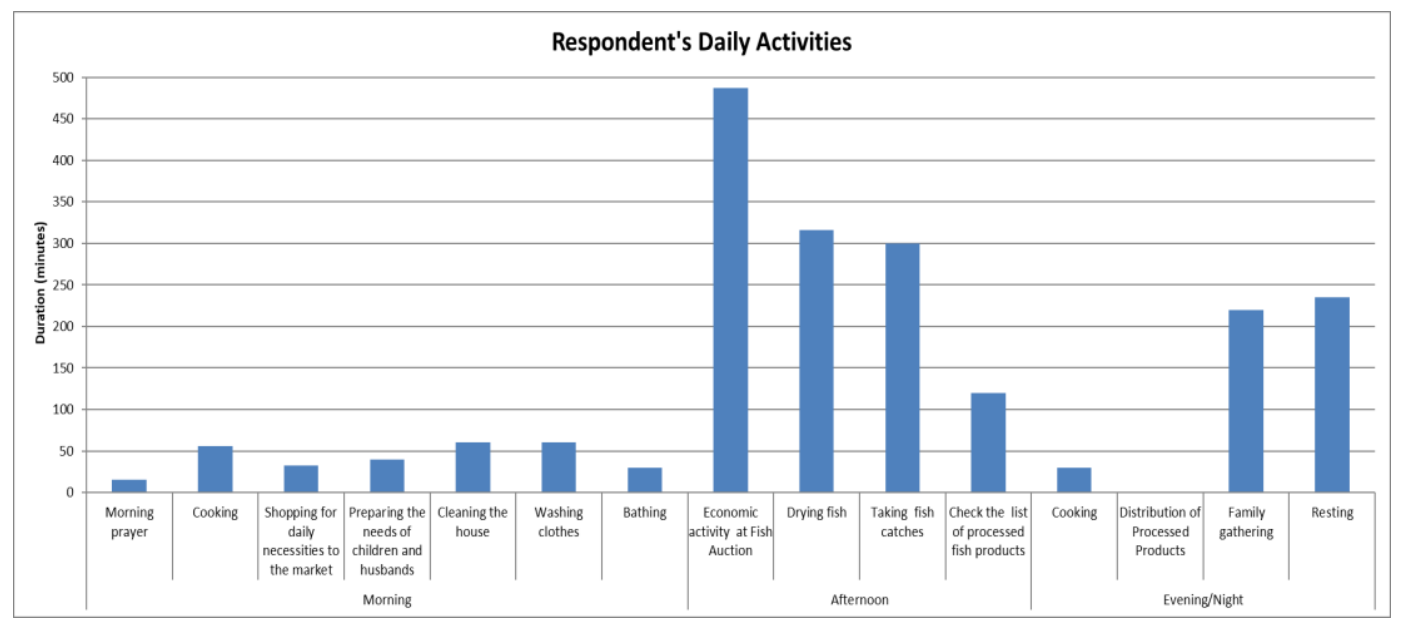

Figure 2. Variety of daily activities carried out by women fishermen

\subsection{Women Fishermen's Time Outpouring}

A percentage description of the results of the calculation of the amount of time spent in one day by women fishermen in Cilacap Regency is presented in Table 3. From the analysis data can be seen from the many activities carried out by fishermen women every day, then activities such as cleaning the house occupies a large outpouring of time. The time outpouring of women fishermen doing activities that are commonly done in the morning is cleaning the house by $21.11 \%$. During the day, the common activity carried out by women fishermen is to conduct economic activities by $44.01 \%$.

Table 3. Percentage of Common Activities Carried out by Fishermen Women One Day

\begin{tabular}{ccc}
\hline Day Time & Percentage & Common types of activities \\
\hline Morning & $21.11 \%$ & cleaning the house (morning) \\
Afternoon & $44.01 \%$ & economic activity (noon) \\
Evening/Night & $34.88 \%$ & resting (night) \\
\hline
\end{tabular}


The activity carried out by women fishermen at night is rest/sleeping, where the time allocation was $34.88 \%$. Related to Figure 3, it can be seen that selling activities in TPI is the most time-consuming activity owned by women fishermen. The time allocated by women fishermen for economic activities explains that women fishermen at the research site also have an important role in making money. Their role in making money is done wholeheartedly to help increase the family's income. It is expected that although women fishermen are also busy helping their husbands work to earn money, they are also able to carry out their roles as good housewives (Alami and Raharjo, 2017; Ramachandran, 2017; Bhargavi et al., 2020; Gunakar and Bhatta, 2016; Venkatalakshmi et al., 2015; Sharma et al., 2012; Devi and Rani, 2000).

\section{Conclussion}

From the results of this study can be concluded that the largest outpouring of time performed by women fishermen is conducting economic activities by $44.01 \%$. The outpouring of time for other activities is resting or taking a break by $34.88 \%$, and house cleaning by $21.11 \%$.

\section{Acknowledgments}

The author would like to thank Universitas Terbuka for providing financial assistance in the 2020 fiscal year through a basic/fundamental research scheme.

\section{References}

Alami, A. N., \& Raharjo, S. N. I. (2017). Recognizing Indonesian fisherwomen's roles in fishery resource management: profile, policy, and strategy for economic empowerment. Journal of the Indian Ocean Region, 13(1), 40-53.

Akpaniteaku, R. C., Weimin, M., \& Xinhua, Y. (2005). Evaluation of the Contribution of Fisheries and Aquaculture to Food Security in Developing Countries. Naga The WorldFish Center Quarterly, 28(1 \& 2), 28-32.

Anna, Z. (2014). The Impact of Financial Assistance on Income: The Case of Women Fish Vendors in North Coast of Java. Asian Fisheries Science Special, (27S), 211-224.

Bhargavi, K., Chirwatkar, B. B., Das, A., Behera, S., \& Bhakta, D. (2020). Socio-economic status of fisherwomen community in coastal Vizianagaram district of Andhra Pradesh, India. Journal of Fisheries, 8(1), 741-745.

Cilacap. (2019). Statistik Daerah Kabupaten Cilacap 2019. Cilacap: Badan Pusat Statistik Kabupaten Cilacap.

Devi, M. I., \& Rani, M. S. V. (2000). The Impact of Globalisation on Coastal Economy and its Implications for Fisherwoman: A Study of Pedda Jalaripet in Visakhapatnam. Development with Human Touch, 46, 1-12.

Fatchiya, A., Kusumastuti, Y. I., \& Mardiana, D. (2005). Profil Wanita Pengolah Ikan di Desa Blanakan Kecamatan Blanakan Kabupaten Subang, Jawa Berat. Buletin Ekonomi Perikanan, 6(1), 37-56.

Gunakar, S., \& Bhatta, R. (2016). Socioeconomic status of Fisher-women in segmented fish markets of coastal Karnataka. Agricultural Economics Research Review, 29(347-2016-17252), 253-266.

Hauzer, M., Dearden, P., \& Murray, G. (2013). The fisherwomen of Ngazidja island, Comoros: fisheries livelihoods, impacts, and implications for management. Fisheries Research, 140, 28-35.

Hutapea, R. Y. F., Kohar, A., \& Rosyid, A. (2012). Peranan Wanita Nelayan (Istri Nelayan) Jaring Insang Dalam Meningkatkan Pendapatan Keluarga Di Desa Bejalen, Perairan Rawa Pening, Kecamatan Ambarawa, Kabupaten Semarang. Journal of Fisheries Resources Utilization Management and Technology, 1(1), 1-10.

Kleiber, D., Harris, L. M., \& Vincent, A. C. J. (2015). Gender and small-scale fisheries: A case for counting women and beyond. Fish and Fisheries, 16(4), 547-562.

Pancawati, Y. D. (2015). Pengembangan kawasan minapolitan (studi kasus: pelabuhan perikanan Samudera Cilacap). Jurnal Pembangunan Wilayah \& Kota, 11(3), 365-376. 
Ramachandran, B. B. (2017). Seafood Kitchen: Survival Strategy of Kerala's Fisherwomen in an Uncertain Economy. International Journal of Rural Management, 13(2), 199-205.

Sharma, A., Sharma, A., \& Saxena, A. (2012). Socio-economic profile and information seeking behavior of fisher women-A study in Uttarakhand. Interaction, 30(2), 31-35.

Venkatalakshmi, V., Vasanthi, P., \& Murali Mohan, M. (2015). Economic and domestic activities of maritime fisher women of north coastal andhra pradesh, east coast of India. International Journal of Current Research, 7(10), 21081-21086. 